\title{
Peculiarity of Magnetoresistance of Composite Materials Based on Co and $\mathrm{SiO}$
}

\author{
I.M. Pazukha*, V.V. Shchotkin, O.V. Pylypenko, V.Z. Mykytyn, Yu.O. Shkurdoda \\ Sumy State University, 2, Rymsky-Korsakov St., 40007 Sumy, Ukraine
}

(Received 01 July 2021; revised manuscript received 06 August 2021; published online 20 August 2021)

\begin{abstract}
A series of thin-film composite materials based on $\mathrm{Co}$ and $\mathrm{SiO}$ were deposited via electron-beam coevaporation technique using two independent sources. The concentration of Co atoms of thin-film composite materials varied from 35 to 90 at. \%. It was controlled by using a scanning electron microscope (Tescan VEGA3) with an energy-scattering X-ray (EDX) detector (Oxford Instruments). The total thickness of the nanocomposites was controlled by a system of two independent quartz resonators and amounted to 30 and $60 \mathrm{~nm}$. The magnetoresistive properties of these structures deposited at room temperature were investigated. The results showed that the percolation threshold for the system based on $\mathrm{Co}$ and $\mathrm{SiO}$ is in the concentration range of $c_{\mathrm{Co}}=60-70$ at. \%. From the field dependences of the magnetoresistance (MR) obtained at room temperature, it follows that the electrical resistance of the films decreases when they are introduced into the magnetic field (negative magnetoresistance). The negative MR indicates that the dominant effect observed is due to spin-dependent electron tunneling between ferromagnetic nanogranules. At the concentration range of $c_{\mathrm{Co}}=40-60$ at. \%, isotropic MR of $1.5-2.5 \%$ is realized. The maximum on the concentration dependences of MR shifts to the region of lower concentrations of Co with increasing sample thickness.
\end{abstract}

Keywords: Composite materials, Co-evaporation, Ferromagnetic particles, Insulator matrix, Magnetoresistance.

\section{INTRODUCTION}

The complex investigation of the crystal structure, phase state, electrophysical, strain, and magnetoresistive properties of nanosized thin-film materials is still one of the urgent problems of the material science [1-4]. The application of various types of such materials (granular nanostructures, cermets, vacuum tunnel junctions, etc.) allows expanding the frontiers of their practical application [5-8]. For example, with combined ferromagnetic and non-magnetic materials, we can form structures with high saturation magnetization at high thermal stability. A large room-temperature magnetoresistance (MR) ratio of up to $40 \%$ at $8 \mathrm{~T}$ can be achieved in structures based on $\mathrm{SiO}_{2}$ films containing surface Fe that made them desirable for high field magnetic sensing applications [9].

Interesting effects in metal/insulator composites were reported in Ref. [10]. It was demonstrated that a nonlinear dependence of current on voltage in the low field regime was observed in $\mathrm{Fe}-\mathrm{Al}_{2} \mathrm{O}_{3}$ granular films. Such non-ohmic resistance at room temperature can be important for properties dependent on electrical currents like the Hall effect, MR, or magnetoimpedance [11]. Besides, the feature of metal/insulator composite materials is a realization of the electrical conductivity owing to electrons tunneling between grains. At this, magnetic and electrical behaviors change significantly when the metal volume fraction is modified [12]. In particular, the realization of the tunnel spin-polarized conductivity allows to find out tunnel magnetoresistance (TMR). So, the question of the percolation threshold becomes very important because the TMR value strongly depends on the composition of thin-film materials $[13,14]$. It should be noted that the mechanisms of MR in granular metal-insulator films are complex and have not yet been fully studied. It can only be noted that the mechanisms of charge and spin transfer in these systems play an important role in the MR formation. In conclusion, the study of magnetoresistive properties of ferromagnetic composite materials based on Co and $\mathrm{SiO}$ is an urgent task for their use as magnetic field sensors with high temperature stability of the MR effect at extreme temperatures. $\mathrm{SiO}$ is the chemical compound, which can be deposited by thermal evaporation and easily form a film with better adhesion.

\section{EXPERIMENT TECHNIQUE}

A series of thin-film composite materials based on $\mathrm{Co}$ and $\mathrm{SiO}$ were deposited by electron-beam coevaporation technique using two independent sources (Co and $\mathrm{SiO}$ ) and two independent electron-beam guns. The samples were deposited onto glass-ceramic substrates at room temperature. In this way, a wide range of compositions was obtained in one deposition run. The deposition conditions included a base pressure of $10^{-4} \mathrm{~Pa}$ and a deposition rate of $5 \mathrm{~nm} / \mathrm{min}$ for Co and $\mathrm{SiO}$. The total thickness of the nanocomposites was controlled by a system of two independent quartz resonators and amounted to 30 and $60 \mathrm{~nm}$. Note, that $\mathrm{SiO}$ is the chemical compound, which can be deposited by evaporation methods [15-17].

Compositional and elemental analysis of thin-film samples was performed by using a scanning electron microscope (Tescan VEGA3) with an energy-scattering X-ray (EDX) detector (Oxford Instruments). For these studies, $5 \times 5 \mathrm{~mm}$ glass-carbon substrates were used. From EDX composite maps for thin-film composite materials based on $\mathrm{Co}$ and $\mathrm{SiO}$, it was found that $\mathrm{Co}, \mathrm{Si}$, and $\mathrm{O}$ are equally distributed in the volume of the film (Fig. 1). This confirms the effectiveness of the method

\footnotetext{
*iryna.pazukha@gmail.com
} 
of co-evaporation for forming thin-film composite materials. The concentration of Co atoms of thin-film composite materials varied from 35 to 90 at. \%.



Fig. 1 - EDS compositional maps of $\mathrm{Co}, \mathrm{Si}$, and $\mathrm{O}$ elements and EDX total spectrum for $(\mathrm{Co}+\mathrm{SiO}) / \mathrm{S}$ composite materials

MR was measured by a four-point probe method in a magnetic field with intensity up to $B=600 \mathrm{mT}$. The MR measurements were carried out with the current in plane configuration in three geometries of the magnetic field relative to the current: longitudinal geometry (magnetic field is in the film plane and parallel to current), transverse geometry (magnetic field is in the film plane and perpendicular to current) and perpendicular geometry (magnetic field is perpendicular to the film plane). The measuring current was $I=1 \mathrm{~mA}$. The MR value was calculated by the following equation: $M R=\left(R(B)-R\left(B_{0}\right)\right) / R\left(B_{0}\right)$, where $R(B)$ is the current value of resistance in the magnetic field $B ; R\left(B_{0}\right)$ is the resistance of the sample in the field $B_{0}$.

The study of the microstructure was carried out by transmission electron microscope TEM-125K.

\section{EXPERIMENTAL RESULTS}

Let us consider the features of electrical conductivity and magnetoresistive properties of thin-film composite materials based on $\mathrm{Co}$ and $\mathrm{SiO}_{x}$. The concentration dependences of the resistivity for nanogranular composites with a thickness of 30 and $60 \mathrm{~nm}$ are shown in Fig. 2. The course of the concentration dependences of the resistivity is typical for granular metal-insulator structures [18]. According to the obtained data, the percolation threshold for the system based on Co and $\mathrm{SiO}$ is in the concentration range of 60-70 at. \%, which agrees well with the literature data for similar structures [19]. Thus, for the data of ferromagnetic nanocomposites we can talk about three modes of conductivity: metallic, transient and insulator. The processes of electrotransfer in the metallic mode are due to the conductivity in the metal layers and are determined by the scattering of conduction electrons at grain boundaries, impurities, and phonons. This mode is implemented when the films consist of electrically continuous metal layers. In the insulator regime, the conductivity is determined by thermally activated tunneling of electrons between metal particles separated by an insulator layer. This mechanism is typical for films with a metal phase concentration below the percolation threshold. In the transient mode, conductivity is a mixture of the two mechanisms mentioned above: metallic conductivity in metal layers and tunneling between individual metal clusters separated by a thin layer of insulator. In this mode, both positive and negative temperature coefficients of resistance can be observed.

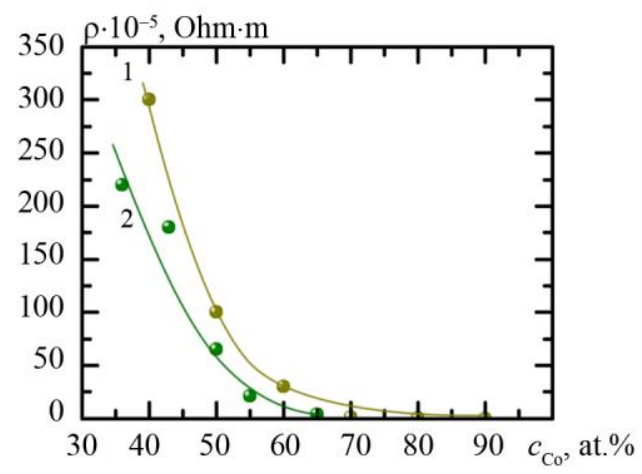

Fig. 2 - The resistivity without an applied magnetic field as a function of Co concentration for as-deposited thin-film composite materials based on $\mathrm{Co}$ and $\mathrm{SiO}$ with thickness $d=30 \mathrm{~nm}$ (1) and $60 \mathrm{~nm}(2)$

In Fig. 3, the field dependences of MR in longitudinal and transverse geometries for as-deposited granular structures based on $\mathrm{Co}$ and $\mathrm{SiO}_{x}$ with a thickness of $60 \mathrm{~nm}$ with different composition of components are illustrated. From the field dependences of the longitudinal MR obtained at room temperature, it follows that the electrical resistance of the films decreases when they are introduced into the magnetic field (negative MR). Field dependences in perpendicular geometry have a similar course. The insignificant mismatch of the curves is due to the lower value of MR in perpendicular geometry. It should be noted that the negative MR indicates that the dominant effect observed is due to spin-dependent electron tunneling between ferromagnetic nanogranules [20]. The value of MR at room temperature is $2.5 \%$ for longitudinal geometry and $2 \%$ for perpendicular one. Also note that the field dependences do not tend to saturate in a magnetic field with induction up to $0.6 \mathrm{~T}$.

Spin-dependent tunneling of electrons in granular structures such as ferromagnetic metal - insulator may be due to the peculiarities of their structure. The results of our electron microscopic studies of the structure of the obtained films allow us to conclude that these films are nanocrystalline with a nanocrystal size less than $5 \mathrm{~nm}$ (Fig. 4). These nanocrystals are immersed in an amorphous matrix. Such a film structure is typical for granular systems. A detailed analysis of diffraction images (Fig. 4) is not possible, and we can only note that the structure of such films is close to amorphous. As a rule, in such systems, due to the chemical interaction of Co with $\mathrm{Si}$ and $\mathrm{O}_{2}$, on the surface of $\mathrm{Co}$ nanoparticles in $\mathrm{SiO}$ we have a mixture of $\mathrm{CoSi}, \mathrm{Co}_{3} \mathrm{Si}$ (ferromagnetic) and $\mathrm{CoO}$ phases (antiferromagnetic) in the matrix and on the surface of Co nanoparticles. 


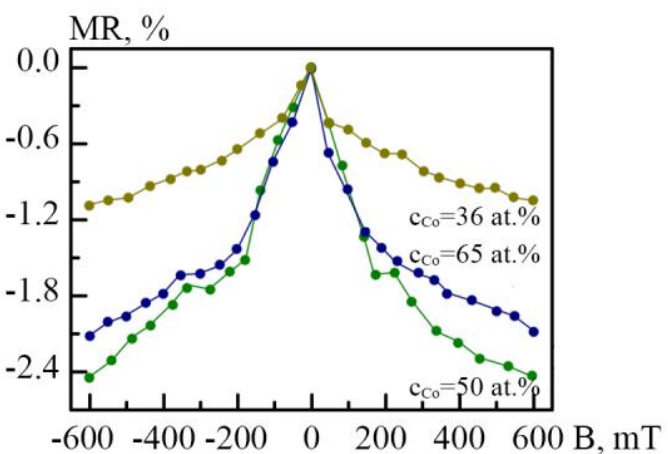

a

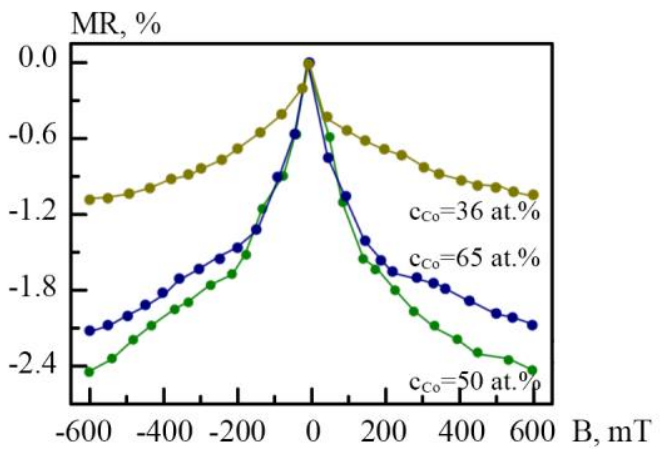

b

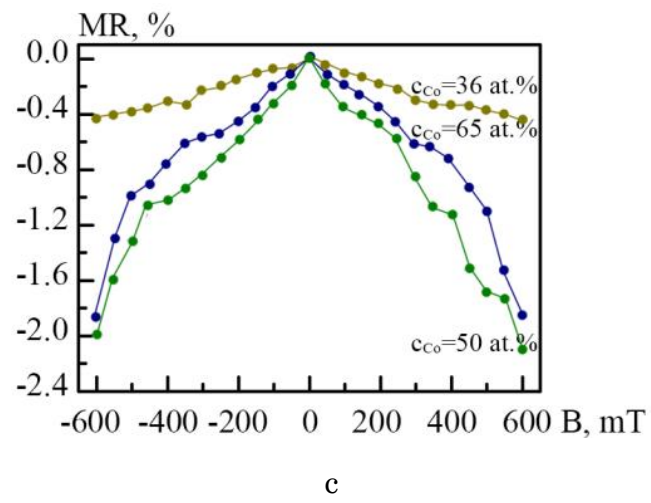

Fig. 3 - Field dependences of longitudinal (a), transverse (b), and perpendicular (c) MR for as-deposited thin-film composite materials based on $\mathrm{Co}$ and $\mathrm{SiO}$ with thickness $d=60 \mathrm{~nm}$ and $c_{\mathrm{Co}}=35,50$ and 65 at. $\%$

The concentration dependences of MR (Fig. 5) are also typical for metal-insulator composites. In the concentration range of 40-60 at. \% (pre-collation zone), isotropic MR of $1.5-2.5 \%$ is realized. At a concentration of Co of 60-70 at. \%, a sharp decrease in the value of TMR is observed. With a further increase in the concentration of $\mathrm{Co}$, the anisotropic nature of $\mathrm{MR}$ appears due to the formation of an infinite ferromagnetic cluster. In this case, field dependences of the anisotropic
MR and its value are typical for freshly condensed Co films (MR does not exceed $0.1 \%$ ). It should also be noted that the maximum on the concentration dependences of MR shifts to the region of lower concentrations of Co with increasing sample thickness.

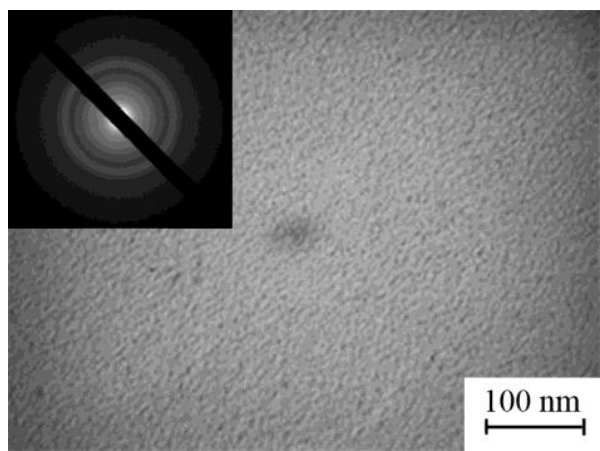

Fig. 4 - Bright field TEM image and diffraction TEM image (in the inset) for thin-film composite materials based on Co and $\mathrm{SiO}$ with thickness $d=30 \mathrm{~nm}$

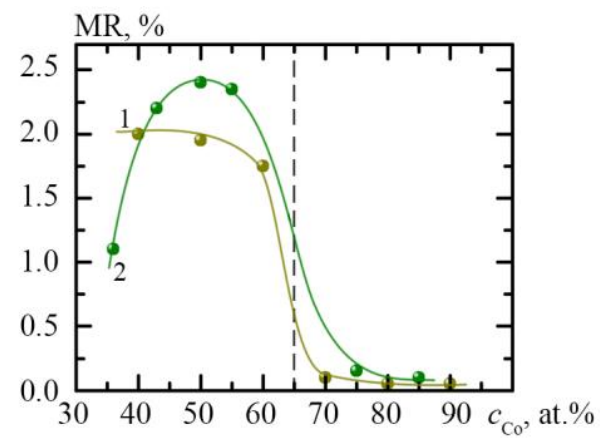

Fig. 5 - MR as a function of the Co concentration for thin-film composite materials based on $\mathrm{Co}$ and $\mathrm{SiO}$ with thickness $d=30 \mathrm{~nm}(1)$ and $60 \mathrm{~nm}(2)$

\section{CONCLUSIONS}

It was found that for as-deposited composites based on $\mathrm{Co}$ and $\mathrm{SiO}_{x}$ with thickness $d=30-70 \mathrm{~nm}$ and $c_{\mathrm{Co}}=40-60$ at. $\%$, isotropic MR of $1.5-2.5 \%$ is realized due to spin-dependent electron tunneling.

The maximum on the concentration dependences of MR shifts to the region of lower concentrations of Co with increasing sample thickness. The reason for such a shift may be the peculiarities of the formation of granular structures depending on their thickness.

\section{ACKNOWLEDGEMENTS}

This work was funded by the state budget programs of the Ministry of Education and Science of Ukraine No. 0119U100777 (2019-2021) and No.0120U102005 (2020-2022).

\section{REFERENCES}

1. D. Lisjak, A. Mertelj, Prog. Mater. Sci. 38 No 9, 2532 (2018).

2. G.V.M. Williams, J. Kennedy, P.P. Murmu, S. Rubanov, S.V. Chong, J. Magn. Magn. Mater. 473, 125 (2019).

3. S.I. Protsenko, L.V. Odnodvorets, I.Yu Protsenko, Springer
Proc. Phys. 156, 345 (2015).

4. I.M. Pazukha, Y.O. Shkurdoda, A.M. Chornous, L.V. Dekhtyaruk, Int. J. Modern Phys. B 33, 1950113 (2019).

5. M.V. Radchenko, G.V. Lashkarev, A.E. Baibara, M.E. Bugaiova, Y.A. Stelmakh, L.A. Krushynskaya, M. Foltyn, W. Knoff, 
T. Story, N. Nedelko, A. Slawska-Waniewska, phys. status solidi b 256, 1900145 (2019).

6. M.V. Radchenko, G.V. Lashkarev, M.E. Bugaiova, O.E. Baibara, Y. Stelmakh, L. Krushinskaya, Y. Dumond, Semicond. Phys. Quantum Electron. Optoelectron. 21 No 2, 125 (2018).

7. A. Hirohata, K. Takanashi, J. Phys. D: Appl. Phys. 19 No 47, 193001 (2014).

8. S.I. Vorobiov, O.V. Shutylieva, I.M. Pazukha, A.M. Chornous, Tech. Phys. 59, 1644 (2014).

9. J. Leveneur, J. Kennedy, G.V.M. Williams, J. Metson, A. Markwitz, Appl. Phys. Lett. 98, 053111 (2011).

10. M.A.S. Boff, S.R. Teixeira, J.E. Schmidt, A.B. Antunes, Appl. Phys. Lett. 85, 757 (2004).

11. M.A.S. Boff, R. Hinrichs, B. Canto, F. Mesquita, D.L. Baptista, G.L.F. Fraga, L.G. Pereira, Appl. Phys. Lett. 105, 143112 (2014).

12. Xiaoli Li, Yanchun Li, Yana Shia, Fanfan Du, Yuhao Bai, Zhiyong Quan, Xiaohong Xu, Mater. Lett. 194, 227 (2017).
13. G.N. Kakazei, Yu.G. Pogorelov, A.M.L. Lopes, J.B. Sousa, S. Cardoso, P.P. Freitas, M.M. Pereira de Azevedo, E. Snoeck, J. Appl. Phys. 90 No 8, 4044 (2001).

14. S. Honda, M.Hirata, M. Ishimaru, J. Magn. Magn. Mater. 290, 1053 (2005)

15. G. Perez, J.M. Sanz, Thin Solid Films 416, 24 (2002).

16. F. Zhou, H.P. Lin, L. Zhang, J. Li, X.W. Zhang, D.B. Yu, X.Y. Jiang, Z.L. Zhang, Curr. Appl. Phys. 12, 228 (2012).

17. H. Kageshima, Y. Yajima, K. Shiraishi, T. Endoh, Jpn. J. Appl. Phys. 58, 111004 (2019).

18. D.A. Balaev, A.D. Balaev, Phys. Solid State 61 No 7, 1203 (2019).

19. G.I. Frolov, O.I. Bachina, M.M. Zav'yalova, S.I. Ravochkin, Tech. Phys. 53, 1059 (2008).

20. S. Honda, T. Ishikawa, K. Takai, Y. Mitarai, H. Harada, J. Magn. Magn. Mater. 290-291, 1063 (2005).

\title{
Особливості магнітоопору композитних матеріалів на основі Со та $\mathrm{SiO}$
}

\author{
І.М. Пазуха, В.В. Щоткін, О.В. Пилипенко, В.З. Микитин, Ю.О. Шкурдода \\ Сумський державний університет, вул. Рислського-Корсакова 2, 40007 Сули, Украйна
}

\begin{abstract}
Серія тонкоплівкових композитних матеріалів на основі Со та $\mathrm{SiO}$ була отримана методом одночасного електронно-променевого осадження з двох незалежних джерел. Концентрація атомів Со у тонкоплівковому зразку змінювалася у межах від 35 до 90 ат. \%. Композиційний та елементний аналіз зразків визначався за допомогою скануючого електронного мікроскопу (Tescan VEGA3) з енергорозсіюючим рентгенівським (EDX) детектором (Oxford Instruments). Загальна товщина композитних матеріалів контролювалася за допомогою системи із двох незалежних кварцових резонаторів та становила 30 та 60 нм. Дослідження магніторезистивних властивостей було проведено для зразків у свіжосконденсованому стані. Згідно з отриманими даними поріг перколяції для системи на основі Со та $\mathrm{SiO}$ знаходиться в інтервалі концентрацій $c_{\mathrm{Co}}=60-70$ ат. \%. Із отриманих за кімнатної температури польових залежностей магнітоопору (МО) слідуе, що електричний опір плівок зменшуеться при внесенні їх у магнітне поле (негативний магнітоопір). Реалізація негативного МО свідчить про те, що домінуючий ефект, який спостерігається, зумовлений спін-залежним тунелюванням електронів між феромагнітними наногранулами. Встановлено, що для свіжосконденсованих композитів на основі Со та $\mathrm{SiO}$ товщиною $d=30-70$ нм та за концентрації $c_{\mathrm{Co}}=40-60$ ат. \% реалізуеться ізотропний $\mathrm{MO}$ величиною 1.5-2.5\%. Максимум на концентраційних залежностях МО зміщуеться в область менших концентрацій Со при збільшенні товщини зразків.
\end{abstract}

Ключові слова: Композитний матеріал, Одночасна конденсація, Феромагнітні частинки, Діелектрична матриця, Магнітоопір. 